Article

\title{
The Role of Product Design in Creating Circular Business Models: A Case Study on the Lease and Refurbishment of Baby Strollers
}

\author{
Deborah Sumter*(1), Conny Bakker and Ruud Balkenende \\ Faculty of Industrial Design Engineering, Delft University of Technology, 2628 CE Delft, The Netherlands; \\ c.a.bakker@tudelft.nl (C.B.); a.r.balkenende@tudelft.nl (R.B.) \\ * Correspondence: d.x.sumter@tudelft.nl
}

Received: 25 June 2018; Accepted: 9 July 2018; Published: 11 July 2018

\begin{abstract}
In the transition to a circular economy companies are exploring new business models, implying a shift from selling products to offering products in circular business models, such as leasing. Product design is thought to play a crucial role in enabling this. Having a robust overview of relevant design roles and competencies is of foundational importance for the development of circular design tools and methods, and for the development of circular economy-based design curricula in higher education. However, how the role of design and the competencies required by designers need to change has hardly been investigated. Building on insights from literature regarding competencies of designers required to consider sustainability, sustainable design, and circular design, we developed a framework in which these competencies are related to the functional, coordinating, and strategic roles that have been recognized within the literature for designers. To complement the results from the literature with insights from practice, a single longitudinal in-depth case study was carried out describing a lease and refurbishment pilot conducted by a Dutch design-driven manufacturer of baby strollers. This case study allowed verification of the literature regarding the functional and coordinating roles of the designer. In addition, we were able to fill the gap observed in the literature regarding the strategic role product designers can assume when designing offers for circular business models. The competencies that we found are (1) the ability to concurrently develop the circular business model and the product's design and (2) the ability to anticipate how the circular offering will evolve over multiple lifecycles. These findings have been used to expand the framework.
\end{abstract}

Keywords: circular economy; product design; refurbishment; alternative ownership model; lease model; design competencies

\section{Introduction}

"A new role for design is to lead clients on the circular economy" [1].

This paper addresses the role of product design in the creation of circular business models. A circular business model describes how an organization creates and captures value in a circular economy; it distinguishes itself from traditional ('linear') models by its focus on high value and high-quality material cycles [2] (p. 45). In the words of Den Hollander, circular business models aim to preserve product integrity to a maximum extent and achieve the most complete cycling of materials possible [3] (p. 84). It is likely that this requires product designers to work more closely with strategic business functions, such as marketing, and, as such, this would recast the role of product design as a co-shaper of business strategy [3].

An example of a circular business model is a combination of an access-based payment model, such as a product lease, with a value recovery strategy, such as refurbishment. Leasing models are thought 
to give manufacturers control over their products over the life cycle and result in reliable product return rates. This would facilitate the recovery of the value embedded in products [4]. Hence, the shift from selling products to providing access-based payment models is considered an important business model for a circular economy. Product design then also includes the design of the associated service.

Product design's role in shaping a circular economy is often described as pivotal. The Ellen MacArthur Foundation, for instance, states: "At its core, a circular economy aims to 'design out' waste. Waste does not exist-products are designed and optimised for a cycle of disassembly and reuse" [4] (p. 7). In a similar vein, Thomas argues "Design will play a key role in the transition to a circular economy" [5]. This sentiment is echoed by the European Commission, for instance, in their recent European Strategy for Plastics in a Circular Economy: “ . . where the design and production of plastics and plastic products fully respect reuse, repair and recycling needs and more sustainable materials are developed and promoted" [6] (p. 5).

In spite of the widespread recognition of the importance of design in a circular economy, there is very little empirical research into the role of design during the development of a circular business model. De Los Rios and Charnley [7], for instance, argue that the current literature lacks case-based evidence of changing skill sets of designers who increasingly need to operate in businesses that prioritize sustainability and circular economy. Having a better understanding of this role and the associated design skills would be of great value for design practitioners and for the education of design students.

This paper aims to identify, map, and complement designers' roles and design competencies for the creation of circular business models in practice with insights from the literature. The term 'competency' is defined as "a functionally linked complex of knowledge, skills, and attitudes that enable successful task performance and problem solving" [8] (p. 204). A detailed insight in design roles and associated competencies forms the foundation for the development of circular design methods and tools, and the development of circular design curricula. The methods used in this study are a literature review and an in-depth analysis of a longitudinal case study of a lease and refurbishment pilot conducted by a Dutch manufacturer of baby strollers. The literature is reviewed in order to develop a framework that organizes different sustainability and circularity-related competencies against three different design roles. The case study is used to verify and (possibly) expand the framework.

The paper is structured as follows: First, the results of the literature review are presented and summarized in a framework. Next, the case study is described and the results are elaborated. Finally, these findings are discussed in order to arrive at an adapted framework.

\section{Background}

In this section we develop a framework in which different roles and competencies of designers are mapped, based on the literature on sustainable and circular design. Design for sustainability is aimed at minimising environmental impact. Circular design strongly focuses on resource efficiency, striving for closed-loop systems. The simultaneous need of economic viability leads to the ambition to maintain product functionality over multiple lifecycles. This makes product lifetime a key concept in a circular economy. Circular design can be considered as a part of design for sustainability with a number of more specific aims.

\subsection{The Changing Role of Design}

Ceschin and Gaziulusoy [9] describe how the role of design for sustainability has been expanding over the past decades, from the development of single products to complex systems, reflecting a shift from relatively isolated design solutions (i.e., improving a product's energy efficiency) to systemic design innovations (i.e., developing a sustainable product-service system). Within this expanding field of influence, three distinct roles for designers can be identified [10]. First, the traditional role of product designers will be referred to as 'functional'. This is a role in which designers are mainly tasked with developing industrially-produced products based on a design brief [11,12], meaning that 
they are involved after the product brief is developed. Second, the coordinating role: a role in which designers build new partnerships, set up stakeholder interactions [13], and balance the interest of these stakeholders $[10,12,14]$. It also entails making internal (personal) connections between departments in order to enhance the understanding and increase team-working [15]. The third role identified in the literature is the strategic role. Designers fulfilling this role are involved in the design process early on [16], determine the scope in which a product or service will be created, develop future visions [17], and initiate and lead projects $[15,18]$.

\subsection{Design Roles and Competencies}

Different roles require different competencies. On a generic sustainability level, not specifically related to product design, Wiek et al. [8] list five competencies that are considered essential to sustainable development: (1) the ability to determine sustainability values and act upon these, which requires the use of sustainability assessment methods such as life cycle assessment (i.e., normative competency); (2) the ability to organize and facilitate collaboration between stakeholders (i.e., interpersonal competency); (3) the ability to design and implement transition strategies aimed at increasing sustainability (i.e., strategic competency); (4) the ability to analyse systems on different levels (i.e., systems-thinking competency); and (5) the ability to create future visions geared towards increasing sustainability (i.e., anticipatory competency). These competencies are also identified by de Haan [19] and Rieckmann [20]. Related to product designers, the first competency can be considered part of a functional design role, the second competency belongs to a coordinating role, while the latter three competencies are related to a strategic role.

Ceschin and Gaziulusoy [9], list the following competencies needed to fulfil strategic and coordinating roles when designing sustainable product-service systems: (1) the ability to address sustainability at an integrated level; (2) the ability to create shared visions to orient innovations; (3) the ability to create relations between different stakeholders; and (4) the ability to facilitate co-design processes. Vezzoli et al. [14] write that designing sustainable product-service systems requires the following strategic competencies: (1) the ability to design an integrated product-service combination that meets a single user demand; (2) the ability to design the stakeholder interactions needed to operationalize a product-service system; and (3) the ability to design locally-based, cohesive offers with the aim to increase eco-efficiency and social equity.

De los Rios and Charnley [7] are the only authors who focused on design competencies specifically for creating closed loop products (i.e., circular business models). Using case study research, they identified ten design competencies necessary to create products for closed loops, based on cases with Nokia, Philips, IKEA, Audi, and others, who developed circular business models. All of the competencies identified relate to functional roles of designers, such as "understand logistics and distribution processes", and "understand the service experience and how to design services" [7] (p. 118). All ten competencies are listed in Table 1. In their discussion of the results of their study, de los Rios and Charnley conclude that "some industrial transformations involve a barely noticeable change in the role of design, ..., while others represent increasing technical challenges for designers or extended responsibilities" [7] (pp. 116-117). 
Table 1. Roles and competencies for sustainable and circular design.

\begin{tabular}{|c|c|c|c|}
\hline $\begin{array}{l}\text { Role of } \\
\text { Designer }\end{array}$ & $\begin{array}{l}\text { General Sustainability } \\
\text { Competencies }\end{array}$ & $\begin{array}{l}\text { Design for Sustainability } \\
\text { Competencies }\end{array}$ & $\begin{array}{c}\text { Design for Circular } \\
\text { Economy Competencies }\end{array}$ \\
\hline & $\begin{array}{l}\text { Wiek et al. [8], de Haan [19], } \\
\text { and Rieckmann [20]. }\end{array}$ & $\begin{array}{l}\text { Ceschin and Gaziulusoy [9], } \\
\text { and Vezzoli et al. [14]. }\end{array}$ & De los Rios and Charnley [7]. \\
\hline \multicolumn{4}{|l|}{ Functional } \\
\hline & $\begin{array}{l}\text { Normative: "Collectively map, } \\
\text { specify, apply, reconcile, and } \\
\text { negotiate sustainability values, } \\
\text { principles, goals, and targets" } \\
\text { [8] (p. 209). }\end{array}$ & & \\
\hline & & $\begin{array}{l}\text { "Design ... the satisfaction of a } \\
\text { particular demand ... and all its } \\
\text { related products and services" } \\
\text { [14] (p. 51). }\end{array}$ & $\begin{array}{l}\text { "Understand the service experience } \\
\text { and how to design services" [7] } \\
\text { (p. 118). }\end{array}$ \\
\hline & & & $\begin{array}{l}\text { "Understand user expectations and } \\
\text { perception of value" [7] (p. 118). } \\
\text { "Understand factors of the use } \\
\text { experience" [7] (p. 118). }\end{array}$ \\
\hline & & & $\begin{array}{l}\text { "Understand processes for reverse } \\
\text { and re-manufacturing" [7] (p. 118). }\end{array}$ \\
\hline & & & $\begin{array}{l}\text { "Assess material physical and } \\
\text { chemical properties" [7] (p. 118). } \\
\text { "Understand product wear by use" [7] } \\
\text { (p. 118). } \\
\text { "Understand engineering functions of } \\
\text { the product" [7] (p. 118). } \\
\text { "Understand failure mode and } \\
\text { maintenance procedures" [7] (p. 118). }\end{array}$ \\
\hline & & & $\begin{array}{l}\text { "Solve aesthetic and structural } \\
\text { problems with limited supplied } \\
\text { components" [7] (p. 118). }\end{array}$ \\
\hline & & & $\begin{array}{l}\text { “Understand logistics and } \\
\text { distribution processes" [7] (p. 118). }\end{array}$ \\
\hline \multicolumn{4}{|l|}{ Coordinating } \\
\hline & $\begin{array}{l}\text { Interpersonal: "Motivate, enable, } \\
\text { and facilitate collaborative and } \\
\text { participatory sustainability } \\
\text { research and problem solving" } \\
\text { [8] (p. 211). }\end{array}$ & $\begin{array}{l}\text { "Design ... the interactions of the } \\
\text { stakeholder of a particular } \\
\text { satisfaction-system" [14] (p. 51). }\end{array}$ & \\
\hline & & $\begin{array}{l}\text { "Acting as facilitator to stimulate a } \\
\text { strategic dialogue and co-design } \\
\text { processes" [9] (p. 149). }\end{array}$ & \\
\hline & & $\begin{array}{l}\text { "Contributing to create relations } \\
\text { between a variety of stakeholders of } \\
\text { a value constellation" [9] (p. 149). }\end{array}$ & \\
\hline \multicolumn{4}{|l|}{ Strategic } \\
\hline & $\begin{array}{l}\text { Strategic: "Collectively design } \\
\text { and implement interventions, } \\
\text { transitions, and transformative } \\
\text { governance strategies toward } \\
\text { sustainability" [8] (p. 210). }\end{array}$ & $\begin{array}{l}\text { "Design ... [offers] that } \\
\text { continuously seeks new, beneficial } \\
\text { eco-efficient and socially equitable, } \\
\text { locally based and cohesive } \\
\text { solutions" [14] (p. 51). }\end{array}$ & \\
\hline & $\begin{array}{l}\text { Systems thinking: "Collectively } \\
\text { analyse complex systems across } \\
\text { different domains ... and across } \\
\text { different scales ...." [8] (p. 207). }\end{array}$ & $\begin{array}{l}\text { "Addressing sustainability } \\
\text { operating on the integrated system } \\
\text { of products, services and } \\
\text { communication through which a } \\
\text { company (or an institution, NGOs } \\
\text { etc.) presents itself" [9] (p. 149). }\end{array}$ & \\
\hline & $\begin{array}{l}\text { Anticipatory: "Collectively } \\
\text { analyse, evaluate, and craft rich } \\
\text { 'pictures' of the future related to } \\
\text { sustainability issues ... " [8] } \\
\text { (p. 207). }\end{array}$ & $\begin{array}{l}\text { "Creating clear, comprehensible and } \\
\text { shared visions to orient innovations" } \\
\text { [9] (p. 149). }\end{array}$ & \\
\hline
\end{tabular}




\subsection{Framework: Competencies Related to the Design for Sustainability and Circularity}

Based on the review of the literature above, it is now possible to map the different design roles and competencies. The framework in Table 1 lists the different roles product designers can assume (i.e., functional, coordinating, and strategic), and the competencies described in literature within the context of sustainability $[8,19,20]$, sustainable design $[9,14]$ and circular design [7]. The competencies are listed from left to right from high-level sustainability to circular-economy specific. Further, similar competencies listed by different authors are categorized in the same row. For instance, Wiek et al. [8], Ceschin and Gaziulusoy [9] and Vezzoli et al. [14] all describe competencies related to organizing and facilitating stakeholder interaction, which are all listed under the coordinating role.

Based on this mapping, a gap was identified; all competencies listed for circular design are of a functional nature. In addition to this paper's main objective of identifying and mapping designers' roles and competencies for the creation of circular business models, we will, therefore, use the case study to seek for evidence of coordinating and strategic roles and competencies for circular design.

\section{Methods}

\subsection{Case Study Research}

We performed case study research on a single, longitudinal case on the development of a lease and remanufacturing system for baby strollers. This specific pilot, which ran over a period of two years as part of a four-year EU H2020 FP7 project, was chosen for two reasons. Firstly, a single longitudinal study allows to dive deep and obtain insight in the details of the case. Dyer and Wilkins [21] argue that studying a single case in depth helps uncover details that are rooted within the context of the case. Given the emerging nature of circular design, such detailed case studies are especially relevant at this stage.

Secondly, baby strollers have received sustained interest in the literature as a promising product for an access model, which provides a basis for comparison with previous work. Mont et al. [22] describe a feasibility study of a lease and remanufacturing business model for baby strollers, noting that the short time of use and high recovery value of the (high quality) baby strollers makes this a very interesting product group for such a business model. Catulli et al., however, find that product-service systems are often too focused on functionality and that highly-visible products, such as baby strollers, require companies to fully understand the "complex symbolism and hedonic value consumers attribute to that product" [23] (p. 7). Clearly, the design of an access model for baby strollers requires the creation of an enticing value proposition, as well as a product that can be refurbished efficiently. This case study thus gives us an opportunity to identify relevant design competencies for different design roles.

The case is recorded from a constructivist viewpoint, meaning that we focus on gathering empirical data from research activities and experiences from individuals in the real world [24,25]. Experiences are reported from the perspective of the individuals involved in the project (i.e., the lead designers).

\subsection{Data Collection}

Data collection was done through desk research (online project documents), informal talks and observations during bi-annual project meetings, design workshops that were held as part of the EU H2020 FP7 project, and semi-structured interviews. Using the project documents, a timeline of the pilot was reconstructed, including the involved parties and the (design) methods and tools used. Next, an interview guide was developed based on the gaps found when constructing the timeline. Three semi-structured interviews [26] were conducted between May and July 2017 at the headquarters of the company and over the phone. The respondents were the Senior Lead Designer (SLD), who is also the Vice President of Sustainability, and the Innovation Marketing Manager (IMM), who has a background in strategic design. They were selected based on their involvement in the EU H2020 FP7 project. Interviews were conducted in Dutch, transcribed verbatim and translated to idiomatic written English during analysis. Additionally, one design workshop was recorded and transcribed verbatim, 
while during the other project meetings extensive notes were taken. Table 2 gives an overview of the topics that we addressed and sample questions per topic.

Table 2. Interview topics and sample questions.

\begin{tabular}{cl}
\hline Topics & \multicolumn{1}{c}{ Sample Question } \\
\hline The EU H2020 FP7 project pilot & $\begin{array}{l}\text { What was the main motivation in setting up the pilot? } \\
\text { Who were involved executing the pilot and what was their role? }\end{array}$ \\
\hline $\begin{array}{c}\text { Role of product design and } \\
\text { designers in a circular economy }\end{array}$ & $\begin{array}{l}\text { Could you elaborate on the main change you had to make to the product design of } \\
\text { the strollers to make them it in your circular value proposition? } \\
\text { Based on your experience within this EU project, how would you describe the role of } \\
\text { industrial design(ers) in the transition towards a circular economy? }\end{array}$ \\
\hline \multirow{2}{*}{ Design process } & $\begin{array}{l}\text { To what extent did you alter you design process to include more } \\
\text { circular considerations? } \\
\text { Could you name a few key decisions in the design process? }\end{array}$ \\
\hline Challenges & $\begin{array}{l}\text { What where the biggest barriers to implementing circularity within Bugaboo? } \\
\text { To what extent did you encounter design dilemmas and how did you deal with this? }\end{array}$ \\
\hline \multirow{2}{*}{ Learnings } & $\begin{array}{l}\text { Which knowledge areas do you see as essential for product designers so that they } \\
\text { assist in developing the circular solution? } \\
\text { What circular opportunities does Bugaboo see for the future based on the pilot? }\end{array}$ \\
\hline
\end{tabular}

\subsection{Data Analysis}

For the analysis of the collected data we followed coding and data reduction strategies [27,28]. First, we applied in vivo coding when coding the interviews line-by-line. This provided us with first-order codes, which we categorized into narrower second-order codes relating to the company, the pilot, design activities, the design process, barriers, learnings, and used methods. The notes that we made during the interviews, workshops and meetings were used as secondary sources that helped substantiate the categories. Next, we analysed the role of the designers by reviewing the type of activities and responsibilities they described and compared these with the roles defined in literature. The competencies were derived by reviewing the barriers and learnings relevant to design. Subsequently, we categorized the competencies based on the classification of roles (i.e., functional, coordinating, and strategic) and contrasted them with the framework in Table 1. Hence, it became clear which competencies corresponded to the ones already found in literature and which new circular competencies emerged based on this case. Lastly, as advised by Voss et al. [29], the participants of the interview were asked to check a draft version of the paper and verify details. This gave them the opportunity to correct factual mistakes.

\section{Results}

This section highlights a selection of findings of the case study research, which are relevant for the identification of design roles and competencies.

\subsection{Background of the Company}

Bugaboo is a Dutch design-driven mobility concept developer established in 1994 and mainly known for developing the world's first modular stroller. Currently, the third generation of the Cameleon is on the market (€999). The company has approximately 1500 employees with 350 working at the headquarters in Amsterdam, including a core innovation team of seventy designers, and the rest spread over offices and factories around the world. The company had an annual turnover of 105 million in 2013. Bugaboo employs a linear business model: the company develops the ideas for its mobility products, manufactures them in its factories in China, and sends them to retailers worldwide, who distribute them to end-users via online and offline channels. Strollers contain recycled content and a limited number of components get recycled at the end of life. Bugaboo offers a warranty of two years and adds one year if customers register their stroller after purchase. Within the warranty period 
customers can get their strollers serviced or maintained. Generally, the strollers disappear out of the company's sight after sales.

\subsection{The Pilot}

Through the EU H2020 FP7 project, Bugaboo was given the opportunity to pilot a circular business model. The pilot's objective was to find a more sustainable, environmentally-friendly, closed-loop product system, whilst staying profitable and continuing to deliver the promise of longer lasting high-quality products. In 2013, at the start of the project, a fast track life cycle assessment (LCA) was conducted to determine the sustainability baseline for Bugaboo's iconic stroller, the Bugaboo Cameleon, of which different versions have been in production for over 15 years. Figure 1 shows the third generation of the Cameleon and its main components. Based on an average product lifetime of 10 years, the LCA showed that the environmental impact is the highest in the production phase. The materials with the largest impact (i.e., plastics and aluminium) are currently only recovered in limited amounts. In addition, connections such as rivets hamper the disassembly of the stroller. The recommendation was to reuse components made from impactful materials, such as the frame, to prolong product lifetime and decrease the relative eco-impact.
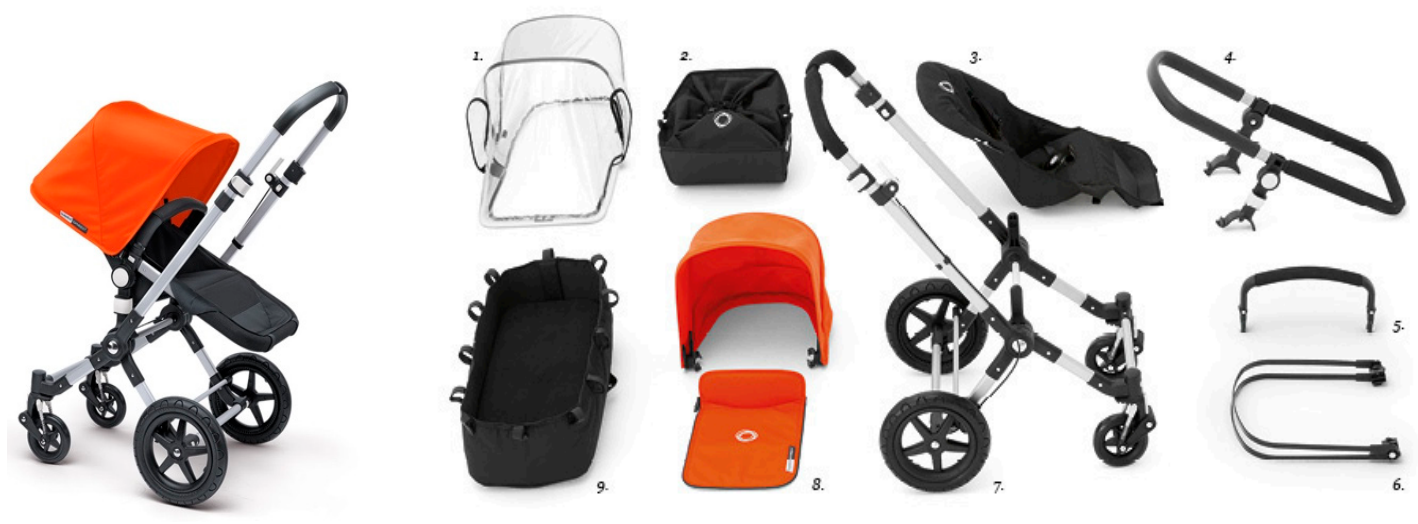

Figure 1. The third generation of the Cameleon line, (left) and the modules of the stroller (right): 1. rain cover, 2 . under seat basket, 3. base seat fabric, 4 . seat/carrycot frame, 5. carry handle, 6 . wireframe, 7. chassis with wheels, 8. extendable sun canopy, and carrycot apron, and 9. base carrycot [30].

Based on the results of the LCA, the sustainability team developed a lease and refurbishment pilot scheme, named The Bugaboo Flex Plan. According to the scheme, the strollers would be leased for two consecutive use cycles and refurbished after each lease cycle (see Figure 2 for a schematic overview). After the second lease cycle, the strollers would be refurbished, certified, and sold on the second-hand market (i.e., Bugaboo Refurbished). Participants could lease the strollers for a period of six months to three years, after which the contract would automatically end. Bugaboo would be responsible for delivering and picking up the stroller at the beginning and end of the contract period, and in cases of required maintenance or a 'swap'.

During the EU H2020 FP7 project, a single lease cycle was piloted. The pilot ran for two years and was conducted in the Netherlands, Bugaboo's most mature market. Flex Plan was advertised through Bugaboo's social media channels. Thirty-five families participated in the pilot. These families were subjected to a credit check to ensure they would be able to pay the monthly fee. Customers paid an initial deposit of $€ 199$, which would be returned at the end of the contract period depending on the condition of the stroller. The monthly fee for the stroller varied between $€ 21$ and $€ 49$ depending on the type of stroller each family leased. In addition, customers paid a small fee for the accessories they selected. Participants were allowed to 'swap' stroller models once a year for $€ 49$. The structure of the pilot resulted in each customer having an individual contract. During the pilot Bugaboo was 
responsible for the logistics (i.e., delivery and pick up), and for maintenance. Strollers were collected by Bugaboo's return logistics partner.

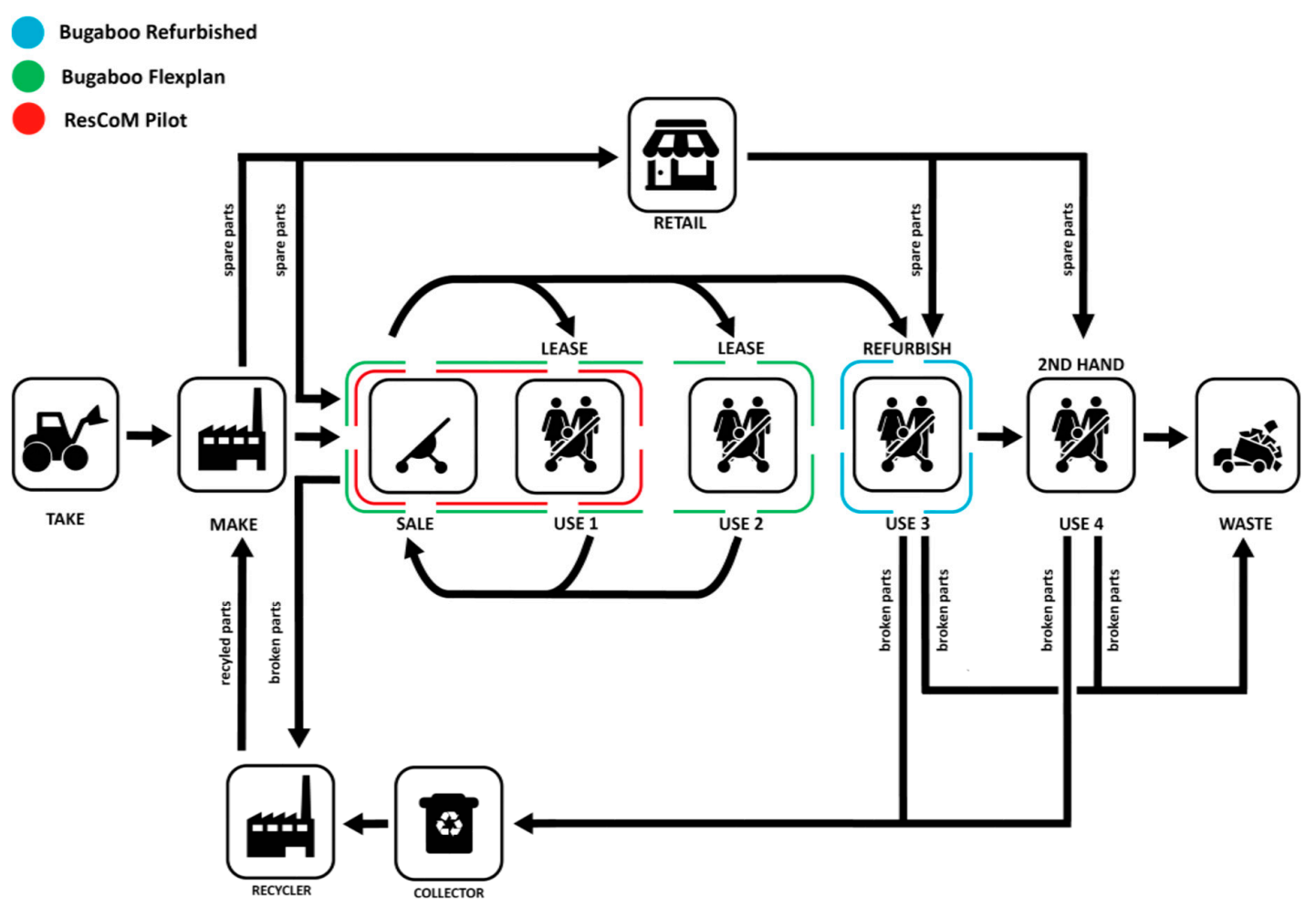

Figure 2. Schematic overview of Bugaboo Flex Plan and Bugaboo Refurbished.

\subsection{Getting Circular Buy-In}

In 2016, the sustainability team hired an innovation marketing manager (IMM) with a background in strategic product design. She helped design, implement and operationalize the pilot, which initially required establishing relationships with all relevant departments: "It was a puzzle. Like, who do we need? Almost all departments". An internal multidisciplinary team, led by the IMM and the SLD, was assembled to get the pilot running. This team included employees from finance, credit control, legal, logistics, service, and two members from management. One of the challenges the IMM and SLD faced was convincing the team members of the benefits of the Flex Plan. In addition to designing the system behind the lease plan, the SLD initially acted as a visionary: "I needed to explain why we actually needed to lease. Why is this good for Bugaboo? Why is it fun? So really communicate a vision and convince people. But also, think along with the team. Like we were a kind of start-up". Convincing employees to buy into the concept of the circular economy and implement the pilot proved to be a challenge on different levels.

First, even though upper management agreed to pilot the Flex Plan, not all middle managers were aware of this. The SLD noted, "some employees were enthusiastic, but [the tasks were] different than they were doing before, so we encountered quite some resistance". Employees commented: "my manager does not allow me to do this" or "it is not part of my Key Performance Indicators" or "we are too busy". For instance, a proposal for a separate webpage announcing the Flex Plan could not be implemented because the brand department, in charge of the website, worked on a large campaign, which meant that there was no opportunity to assist with the webpage.

Second, differences in mindsets hindered the implementation of the pilot. The SLD was used to thinking conceptually. However, not all employees, had the same mindset. Initially the SLD forgot to convey his vision regarding Flex Plan and the benefits for Bugaboo. When asked how he would describe the activities that come with pushing the transition towards a circular economy, the SLD 
mentioned (1) thinking about new business models and pushing the implementation of these business models within the company whenever he thought it would be good for the company; (2) pushing others to think about circularity; and (3) convincing management. The SLD emphasized that convincing management, in particular, is essential because "without getting buy-in from management it takes a lot of energy to push the sustainability agenda".

\subsection{Outcomes of the Pilot-Consequences for the Design of the Strollers}

The pilot showed that Bugaboo had to do more refurbishment than expected; one third of the returned strollers were highly damaged. Due to the use of rivets the broken frames could not be repaired, but had to be replaced instead, which was very costly. This resulted in a debate about the extent to which Bugaboo should refurbish the strollers. A high degree of refurbishment (i.e., replacing all broken parts, as well as parts with cosmetic damage) would negatively affect the eco-impact. On the other hand, only replacing broken parts might affect the company's brand image, because it was assumed that customers would not accept cosmetic damage in otherwise fully-functional products. As a consequence, the sustainability team started reflecting on the lease-readiness of the strollers. The irreversibility of rivet connections was a problem, and so was the material of the frame. While the aluminium frame is recyclable, it is also scratch-sensitive, which makes it less attractive for a product with multiple use cycles. The team discussed which circular product design strategy would fit the lease model best: "Do you make the stroller more repairable on parts-level or do you make the stroller more durable on product-level?" While the first approach means designing modules that can be easily exchanged between use cycles, the latter approach means making the stroller, as a whole, as robust as possible. This affects the choice of materials and connecting mechanisms. In addition, the team realized that developing new accessories in a lease and refurbishment model requires that these are compatible across all stroller lines and generations. The SLD commented: "At some point, we want to develop a generic interface for all of our accessories".

As a result of the lease-readiness discussions, the team created Products to last: a categorization of parts with different lifetime requirements. Table 3 gives an overview of the four lifetime categories with examples. This categorization served as a guide to improve the modularity of the stroller and helped gain insights in redesign opportunities that would improve the readiness for lease and refurbishment.

Table 3. Product to last-part lifetime categorization. Some examples from the part lifetime list.

\begin{tabular}{ccccc}
\hline Categories & Long Lasting & Wear and Tear & Packaging \\
\hline $\begin{array}{c}\text { Example } \\
\text { part }\end{array}$ & $\begin{array}{c}\text { Bugaboo Cameleon } \\
\text { Frame }\end{array}$ & $\begin{array}{c}\text { Bugaboo Cameleon } \\
\text { Snow wheel }\end{array}$ & $\begin{array}{c}\text { Bugaboo Cameleon } \\
\text { Carry cot }\end{array}$ & $\begin{array}{c}\text { Bugaboo Cameleon } \\
\text { Car seat adapter } \\
\text { packaging }\end{array}$ \\
\hline \multirow{2}{*}{ Lifecycle } & $\begin{array}{c}\text { Lasts for three } \\
\text { use cycles }\end{array}$ & $\begin{array}{c}\text { Degrades during } \\
\text { one use cycle }\end{array}$ & $\begin{array}{c}\text { Replaced every use } \\
\text { cycle (in lease model) }\end{array}$ & One-time use \\
\hline
\end{tabular}

\subsection{Challenges for Scaling of the Pilot}

The Flex Plan was designed to be very flexible; customers could swap strollers once per year and add accessories anytime. According to the IMM, this was a necessary part of an enticing value proposition: "For [customers] to think [the Flex Plan] was attractive, we had to offer more than in the case of buying". It turned out that customers used this option extensively, which resulted in increased 
logistics and costs. The IMM mentioned, "We often had to drive up and down. Even when customers wanted to change colours from pink to blue". As a consequence, the sustainability team debated whether they should restrict the number of times customers could exchange strollers and accessories, and worried about whether such restrictions would affect customer interest.

Since Bugaboo had no previous experience in working with a leasing model, the implementation of the pilot triggered new information flows within and between departments, causing unexpected delays. For example, before Flex Plan participants could receive their strollers, they had to wait for Bugaboo to send a lease contract. After signing the contract, Bugaboo had to perform a credit check and co-sign the contract. The stroller would then be prepared and sent to the participating customer. The SLD noted: "The first time that we mapped everything and determined the lead time, it turned out the delivery time would be around three months. We thought this was not really convenient, because customers would have to wait for three months until they got their stroller".

The work flow also resulted in new information flows between departments and customers. For instance, the finance department had to directly deal with the participating customers during the pilot. Employees from the finance department, however, were used to communicating with other companies, not with customers. The service department had to step in and take over some tasks that initially were assigned to the finance department.

The sustainability team soon realized that offering multiple strollers simultaneously as part of the Flex Plan would result in problems with refurbish-readiness and compatibility issues. The SLD commented, "I can imagine that, when you get back all products and they have different qualities and it is a mix of old and new, you need an infrastructure to determine which components can be used for certain products". Bugaboo realized that in order to scale the leasing scheme, the company would need to implement a track and trace software system to gain control over its resources. In addition, the software system was not equipped to deal with these new information flows.

In short, when piloting the lease scheme, the company realized its strengths and weaknesses. The SLD: “Bugaboo is very good at designing and producing high quality innovative mobility solutions. Its strength is not in chasing people who still need to pay their monthly lease fee".

\section{Discussion}

The objective of this paper is to identify and map designers' roles and design competencies for the creation of circular business models. In the Bugaboo case, all three design roles (functional, coordinating, and strategic) can be identified. The case study insights are used to distill design competencies for each of the three roles. These are subsequently compared to the framework of design competencies in Table 1.

\subsection{Functional Role and Competencies}

An unexpected negative result of the lease pilot was the return of one third of the strollers in a severely damaged condition. It shows the need to investigate how leasing might affect the sense of ownership and the willingness of consumers to take good care of the leased products. Relevant competencies in this respect were identified by de los Rios and Charnley [7]: "understanding user expectations and perception of value", "understanding factors of the use experience", and "understanding the service experience and how to design services".

Of the other functional competencies that were identified by de los Rios and Charnley, most can be recognized, for instance, "understanding processes for reverse and re-manufacturing" and "understanding failure mode and maintenance procedures" were some learnings from the Flex Plan case. The SLD made some commented related to this: "It is really important to take those people together with you on a journey regarding the ideas about refurbishing. Like, 'How do you ensure that a product is easy to refurbish or how do you guarantee that at the end of life the product does not harm the environment too much?' I feel designers and engineers can have the most impact on this". 
Another functional competency that we observed stems from the instance where the sustainability team reviewed two potentially competing circular design strategies. Design for durability and design for reparability could both facilitate refurbishment but would have different consequences regarding manufacturing and environmental impact. Hence, this implies that product designers need to be able to assess and compare the environmental impact of different circular strategies. Recovery and multiple lifecycles are crucial elements of the circular economy, resulting in the timeframe being an important element as well. From this case we, thus, derive the following competency:

\section{(1) Estimate the environmental impact on a system level over multiple life cycles}

\subsection{Coordinating Role and Competencies}

Regarding the coordinating role, the case study showed that shifting to a leasing model required close internal collaboration. As a consequence of piloting a lease model, new flows of information became apparent between departments. The SLD and IMM created a multidisciplinary team and coordinated the setup and operation of the pilot. The associated competency was described by Ceschin and Gaziulusoy [9] as "contribute to create relations between a variety of stakeholders of a value constellation". Based on this case study, we can further specify this competency for circular design as:

\section{(2) Facilitate collaboration between internal and external stakeholders who play a role in operationalizing a circular business model}

The sustainability literature (e.g., $[8,19,20])$ refers to this as an interpersonal competency in the context of successful stakeholder collaboration. The case study clearly shows the importance of organizing and facilitating stakeholder interaction in the creation of circular business models.

\subsection{Strategic Role and Competencies}

The main role that the SLD fulfilled was strategic: The SLD was involved in both designing the value proposition, which can be seen as a management task, as well as setting up and leading teams and extracting learnings from the pilot. Based on the case we identified a number of strategic competencies.

First, the limited lease and refurbish-readiness of the stroller affected the results of the pilot. An integrated approach in which the development of products and services happens concurrently is, therefore, important. This has also been stated by Ceschin and Gaziulusoy [9] in light of the expanding scope of design, which has moved from product focus to systems focus. These authors describe the designer's ability to address sustainability by applying an integrated system approach. Building on this case we formulate the following strategic competency:

\section{(3) Concurrently develop the circular business model and the product's design}

Second, within this case we observed that planning and anticipating on the future consequences of product development became increasingly important. For instance, creating a universal interface would aid the exchange of parts between models and generations, but would also affect the compatibility with older models. It was deduced that product designers should be able to plan the development of modules and interfaces over time, develop refurbishment schedules, and think about forward and backward compatibility. In contrast to product development, which is finished after the product's launch, circular business development requires designers to stay involved in solving issues throughout the service life of the product [31]. When designing for a circular economy, designers explicitly need to consider temporal aspects, such as the technical product lifetime and length of the use cycle. This affects the horizontal (i.e., product lines) and vertical (i.e., product generations) product development, as became apparent in the case. Building on this, we derive the following strategic competency: 


\section{(4) Anticipate how the circular offering will evolve over multiple lifecycles}

This is associated with the anticipatory competency (e.g., $[8,19,20])$, which is about envisioning possible future scenarios.

\subsection{Adapting the Framework}

Table 4 shows the adapted framework with the new competencies that were derived from the case study added in bold. The Bugaboo case proved to be of great value. It both offered the opportunity to verify the functional competencies as identified by de Los Rios and Charnley [7], and also identified additional competencies, in particular those related to the strategic role of designers.

Table 4. Roles and competencies for sustainable and circular design (extended). New competencies based on the case study are added in bold).

\begin{tabular}{|c|c|c|c|}
\hline $\begin{array}{l}\text { Role of } \\
\text { Designer }\end{array}$ & $\begin{array}{l}\text { General Sustainability } \\
\text { Competencies }\end{array}$ & $\begin{array}{l}\text { Design for Sustainability } \\
\text { Competencies }\end{array}$ & $\begin{array}{l}\text { Design for Circular } \\
\text { Economy Competencies }\end{array}$ \\
\hline Sources & $\begin{array}{l}\text { Wiek et al. [8], de Haan [19], } \\
\text { and Rieckmann [20]. }\end{array}$ & $\begin{array}{l}\text { Ceschin and Gaziulusoy [9], } \\
\text { and Vezzoli et al. [14]. }\end{array}$ & De los Rios and Charnley [7]. \\
\hline \multirow{7}{*}{ Functional } & $\begin{array}{l}\text { Normative: "Collectively map, } \\
\text { specify, apply, reconcile, and } \\
\text { negotiate sustainability values, } \\
\text { principles, goals, and targets" } \\
\text { [8] (p. 209). }\end{array}$ & & $\begin{array}{l}\text { Estimate the environmental } \\
\text { impact on a system level over } \\
\text { multiple life cycles. }\end{array}$ \\
\hline & & $\begin{array}{l}\text { "Design ... the satisfaction of a } \\
\text { particular demand ... and all its } \\
\text { related products and services" [14] } \\
\text { (p. 51). }\end{array}$ & $\begin{array}{l}\text { "Understand the service experience } \\
\text { and how to design services" [7] } \\
\text { (p. 118). }\end{array}$ \\
\hline & & & $\begin{array}{l}\text { "Understand user expectations and } \\
\text { perception of value" [7] (p. 118). } \\
\text { "Understand factors of the use } \\
\text { experience" [7] (p. 118). }\end{array}$ \\
\hline & & & $\begin{array}{l}\text { "Understand processes for reverse } \\
\text { and re-manufacturing" [7] (p. 118). }\end{array}$ \\
\hline & & & $\begin{array}{l}\text { "Assess material physical and } \\
\text { chemical properties" [7] (p. 118). } \\
\text { "Understand product wear by use" } \\
\text { [7] (p. 118). } \\
\text { "Understand engineering functions } \\
\text { of the product" [7] (p. 118). } \\
\text { "Understand failure mode and } \\
\text { maintenance procedures" [7] } \\
\text { (p. 118). }\end{array}$ \\
\hline & & & $\begin{array}{l}\text { "Solve aesthetic and structural } \\
\text { problems with limited supplied } \\
\text { components" [7] (p. 118). }\end{array}$ \\
\hline & & & $\begin{array}{l}\text { "Understand logistics and } \\
\text { distribution processes" [7] (p. 118). }\end{array}$ \\
\hline \multirow{3}{*}{ Coordinating } & $\begin{array}{l}\text { Interpersonal: "Motivate, enable, } \\
\text { and facilitate collaborative and } \\
\text { participatory sustainability } \\
\text { research and problem solving" } \\
\text { [8] (p. 211). }\end{array}$ & $\begin{array}{l}\text { "Design ... the interactions of the } \\
\text { stakeholder of a particular } \\
\text { satisfaction-system" [14] (p. 51). }\end{array}$ & $\begin{array}{l}\text { Facilitate collaboration between } \\
\text { internal and external stakeholders } \\
\text { who play a role in } \\
\text { operationalizing a circular } \\
\text { business model. }\end{array}$ \\
\hline & & $\begin{array}{l}\text { "Acting as facilitator to stimulate a } \\
\text { strategic dialogue and co-design } \\
\text { processes" [9] (p. 149). }\end{array}$ & \\
\hline & & $\begin{array}{l}\text { "Contributing to create relations } \\
\text { between a variety of stakeholders of } \\
\text { a value constellation" [9] (p. 149). }\end{array}$ & \\
\hline
\end{tabular}


Table 4. Cont.

\begin{tabular}{|c|c|c|c|}
\hline $\begin{array}{l}\text { Role of } \\
\text { Designer }\end{array}$ & $\begin{array}{l}\text { General Sustainability } \\
\text { Competencies }\end{array}$ & $\begin{array}{l}\text { Design for Sustainability } \\
\text { Competencies }\end{array}$ & $\begin{array}{c}\text { Design for Circular } \\
\text { Economy Competencies }\end{array}$ \\
\hline \multirow{3}{*}{ Strategic } & $\begin{array}{l}\text { Strategic: "Collectively design and } \\
\text { implement interventions, } \\
\text { transitions, and transformative } \\
\text { governance strategies toward } \\
\text { sustainability" [8] (p. 210). }\end{array}$ & $\begin{array}{l}\text { "Design ... [offers] that } \\
\text { continuously seeks new, beneficial } \\
\text { eco-efficient and socially equitable, } \\
\text { locally based and cohesive } \\
\text { solutions" [14] (p. 51). }\end{array}$ & $\begin{array}{l}\text { Concurrently develop the circular } \\
\text { business model and the } \\
\text { product's design. }\end{array}$ \\
\hline & $\begin{array}{l}\text { Systems thinking: "Collectively } \\
\text { analyse complex systems across } \\
\text { different domains ... and across } \\
\text { different scales ...." [8] (p. 207). }\end{array}$ & $\begin{array}{l}\text { "Addressing sustainability } \\
\text { operating on the integrated system } \\
\text { of products, services and } \\
\text { communication through which a } \\
\text { company (or an institution, NGOs } \\
\text { etc.) presents itself" [9] (p. 149). }\end{array}$ & \\
\hline & $\begin{array}{l}\text { Anticipatory: "Collectively } \\
\text { analyse, evaluate, and craft rich } \\
\text { 'pictures' of the future related to } \\
\text { sustainability issues...." [8] } \\
\text { (p. 207). }\end{array}$ & $\begin{array}{l}\text { "Creating clear, comprehensible and } \\
\text { shared visions to orient innovations" } \\
\text { [9] (p. 149). }\end{array}$ & $\begin{array}{l}\text { Anticipate how the circular } \\
\text { offering will evolve over } \\
\text { multiple lifecycles. }\end{array}$ \\
\hline
\end{tabular}

It should be noted that these new competencies were derived from a single-case study, which makes it difficult to generalize the results. Nevertheless, the in-depth nature of the case study, its design-driven character, and the fact that it was possible to follow the development and operation of the lease and refurbishment pilot for almost two years, adds to the robustness of the results.

Further research should focus on validating the identified set of circular competencies by conducting multiple-case study research. Additionally, analysing cases in which companies piloted or adopted other business models in the context of a circular economy will help to further uncover the competencies that go along with the different design roles.

\section{Conclusions}

This paper described a single, longitudinal case in which a design-driven original equipment manufacturer (OEM) piloted a circular business model (e.g., leasing of strollers combined with refurbishment). The paper aimed to identify and map designers' roles and associated design competencies for the creation of circular business models. This is relevant because there is still very little empirical evidence of how designers' roles and competencies are changing as a result of the increasing business attention for sustainable and circular models. Having a robust overview of relevant design roles and competencies is of foundational importance for the development of circular design tools and methods, and for the development of circular economy-based design curricula in higher education.

The paper developed a framework which distinguishes between three design roles identified in the literature (i.e., functional, coordinating, and strategic) and the relevant competencies for each role. Using a literature review and a case study analysis, we identified a range of competencies. Most notable, because they were first identified in the case study, are the strategic competencies that support design for a circular economy.

First, concurrently developing the circular business model and the product's design, the case convincingly showed how important it was to have a 'lease-ready' stroller, as the different demands that are set to a stroller that is returned and needs refurbishment could not be met with the original design and the different (less careful) user behaviour was not accounted for.

Second, are the anticipatory and 'planning-ahead' competencies that are needed to design a product that must stay relevant, desired, and cost-effective over multiple use cycles. Lease products come back in between use cycles and undergo a value recovery intervention, such as refurbishment. Hence, it becomes essential to put effort in planning temporal aspects, such as technical product lifetime and use cycles. This could affect forward and backward compatibility of product lines, as well as horizontal and vertical product development. 
While these competencies need to be further validated, it is striking to see their importance. It is clear that the role of product design will, and must, expand to assist businesses in going circular. This paper has given a first insight into the strategic design roles and competencies that are likely to shape the design methodology and design education for decades to come.

Author Contributions: D.S. is the corresponding author of this manuscript. She is the primary author of this manuscript. She was in charge of collecting and analysing the data, wrote the initial drafts of the full paper, and produced the images for this manuscript. C.B. and R.B. supervised her in this process and contributed to reviewing the paper internally. All authors read and approved the final manuscript.

Funding: This research was funded by the Resource Conservative Manufacturing (ResCoM) project from the European Union's seventh Framework Program for research, technological development, and demonstration under grant agreement no. 603843.

Acknowledgments: The authors also would like to thank the interviewed designers for their participation. In addition, the authors would like to thank Bugaboo for its collaboration.

Conflicts of Interest: The authors declare no conflict of interest. The funding sponsors had no role in the design of the study; in the collection, analyses, or interpretation of data; in the writing of the manuscript; or in the decision to publish the results.

\section{References}

1. Sherwin, C. Forum for the Future: The Changing Role of the Designer in the Circular Economy. Available online: http:/ / www.forumforthefuture.org/blog/changing-role-designer-circular-economy (accessed on 20 June 2018).

2. Korhonen, J.; Honkasalo, A.; Seppälä, J. Circular Economy: The Concept and Its Limitations. Ecol. Econ. 2018, 143, 37-46. [CrossRef]

3. Den Hollander, M.C. Design for Managing Obsolescence: A Design Methodology for Preserving Product Integrity in a Circular Economy. Ph.D. Thesis, Delft University of Technology, Delft, The Netherlands, 15 June 2018.

4. Ellen MacArthur Foundation. Towards the Circular Economy: Economic and Business Rationale for an Accelerated Transition; Ellen MacArthur Foundation: London, UK, 2013.

5. Thomas, S. Investigating the Role of Design in the Circular Economy; The Great Recovery: London, UK, 2013.

6. European Commission. Closing the Loop: An Ambitious EU Circular Economy Package. Available online: http:/ / ec.europa.eu/environment/circular-economy/pdf/plastics-strategy-brochure.pdf (accessed on 20 June 2016).

7. De los Rios, I.C.; Charnley, F.J.S. Skills and Capabilities for a Sustainable and Circular Economy: The Changing Role of Design. J. Clean. Prod. 2016, 160, 109-122. [CrossRef]

8. Wiek, A.; Withycombe, L.; Redman, C.L. Key Competencies in Sustainability: A Reference Framework for Academic Program Development. Sustain. Sci. 2011, 6, 203-218. [CrossRef]

9. Ceschin, F.; Gaziulusoy, I. Evolution of Design for Sustainability: From Product Design to Design for System Innovations and Transitions. Des. Stud. 2016, 47, 118-163. [CrossRef]

10. Sumter, D.X.; Bakker, C.A.; Balkenende, A.R. The Role of Product Designers in the Transition towards the Circular Economy: A Reality Check. In Proceedings of the 2nd Product Lifetimes and the Environment Conference, Delft, The Netherlands, 8-10 November 2017; Bakker, C.A., Mugge, R., Eds.; IOS Press BV: Amsterdam, The Netherlands, 2017; p. 391.

11. Julier, G. The Culture of Design, 2nd ed.; Sage Publications: London, UK, 2007; ISBN 1412930464.

12. Manzini, E.; Coad, R. Design, When Everybody Designs: An Introduction to Design for Social Innovation; MIT Press: Cambridge, MA, USA, 2015; ISBN 9780262028608.

13. Tan, L. Understanding the Different Roles of the Designer in Design for Social Good: A Study of Design Methodology in the DOTT 07 (Designs of the Time 2007) Projects. Ph.D. Thesis, Northumbria University, Newcastle, UK, 21 March 2012.

14. Vezzoli, C.; Kohtala, C.; Srinivasan, A. Product-Service System Design for Sustainability, 1st ed.; Greenleaf Publishing Limited: Sheffield, UK, 2014; ISBN 978-1-909493-69-8.

15. Perks, H.; Cooper, R.; Jones, C. Characterising the Role of Design in a New Product Development: An Empirically Derived Taxonomy. J. Prod. Innovat. Manag. 2005, 22, 111-127. [CrossRef] 
16. Behrisch, J. Incorporating Ecological Considerations into Industrial Design Practice. Ph.D. Thesis, University of Technology, Sydney, Australia, 7 July 2013.

17. Joore, P. New to Improve: The Mutual Influence between New Products and Societal Processes. Ph.D. Thesis, Delft University of Technology, Delft, The Netherlands, 30 November 2010.

18. Seidel, B.V. Moving from Design to Strategy: The Four Roles of Design-Led Strategy Consulting. Des. Manag. J. 2000, 11, 35-40. [CrossRef]

19. De Haan, G. The BLK '21' Programme in Germany: A Gestaltungskompetenz-based Model for Education for Sustainable Development. Environ. Educ. Res. 2006, 12, 19-32. [CrossRef]

20. Rieckmann, M. Future-Oriented Higher Education: Which Key Competencies Should Be Fostered through University Teaching and Learning? Futures 2012, 44, 127-135. [CrossRef]

21. Dyer, W.G.; Wilkins, A.L. Better Stories, Not Better Constructs, to Generate Better Theory: A Rejoinder to Eisenhardt. Acad. Manag. Rev. 1991, 16, 613-619. [CrossRef]

22. Mont, O.; Dalhammar, C.; Jacobsson, N. A New Business Model for Baby Prams Based on Leasing and Product Remanufacturing. J. Clean. Prod. 2006, 14, 1509-1518. [CrossRef]

23. Catulli, M.; Cook, M.; Potter, S. What Value Do Consumers Really Expect of Product Service Systems? Reflections on How a Different Conception of Value Could Facilitate the Implementation of PSS in Consumer Markets. In Proceedings of the Sustainable Innovation 2014-19th International Conference, Copenhagen, Denmark, 3-4 November 2014.

24. Prendeville, S.M.; O'Connor, F.; Bocken, N.M.P.; Bakker, C. Uncovering Ecodesign Dilemmas: A Path to Business Model Innovation. J. Clean. Prod. 2016, 143, 1327-1339. [CrossRef]

25. Moses, J.; Knutsen, T. Ways of Knowing: Competing Methodologies in Social and Political Research, 2nd ed.; Palgrave Macmillan: London, UK, 2012; ISBN 0230360696.

26. Patton, M.Q. Qualitative Interviewing. In Qualitative Research E Evaluation Methods, 4th ed.; Sage Publications: Thousand Oacks, CA, USA, 2002; pp. 339-428, ISBN 9780761919711.

27. Miles, M.; Huberman, A.M. Qualitative Data Analysis, 1st ed.; Sage Publications: Beverly, CA, USA, 1984; ISBN 978-0803922747.

28. Charmaz, K. Coding in Grounded Theory Practice. In Constructing Grounded Theory: A Practical Guide Through Qualitative Analysis, 1st ed.; Sage Publications Ltd.: London, UK, 2006; pp. 42-66, ISBN 9780761973539.

29. Voss, C.; Tsikriktsis, N.; Frohlich, M. Case Research in Operations Management. Int. J. Oper. Prod. Manag. 2002, 22, 195-219. [CrossRef]

30. Bugaboo Cameleon ${ }^{3}$. Available online: http://www.bugaboo.com/AU/en_AU/strollers/bugaboocameleon3 (accessed on 23 Auguest 2016).

31. Diehl, J.C.; Christiaans, H. Product Service Systems: The Future for Designers? The Changing Role of the Industrial Designer. In Proceedings of the International Design Congress of KSDS and Adada with Cumulus, Gwangju, Korea, 17-23 October 2015.

(C) 2018 by the authors. Licensee MDPI, Basel, Switzerland. This article is an open access article distributed under the terms and conditions of the Creative Commons Attribution (CC BY) license (http:/ / creativecommons.org/licenses/by/4.0/). 